\title{
Acıgöl Grabeni Kuzeyindeki Pliyo-Kuvaterner Yaşlı Karasal Çökellerin Fasiyes Özellikleri ve Bölgenin Paleoortamsal Gelişimi, GB-Türkiye
}

\author{
Ezher TAGLIASACCHI*1 (1), Fuzuli YAĞMURLU2 ${ }^{2}$ (])
}

1Pamukkale Üniversitesi, Mühendislik Fakültesi, Jeoloji Mühendisliği Bölümü, 20070, Denizli, Türkiye ${ }^{2}$ Süleyman Demirel Üniversitesi, Mühendislik Fakültesi, Jeoloji Mühendisliği Bölümü, 32260, Isparta, Türkiye

(Alınış / Received: 21.09.2018, Kabul / Accepted: 07.08.2019, Online Yayınlanma / Published Online: 30.08.2019)

\section{Anahtar Kelimeler}

Litofasiyes,

Karasal tortullar, Pliyo-Kuvaterner, Acıgöl Grabeni, GB-Türkiye
Özet: Denizli'nin 65 km kuzeydoğusundaki Pliyosen ve Kuvaterner yaşlı karasal çökellerin sedimantolojik özellikleri ve bu çökellerin tektono-sedimanter gelişimi bu çalışmanın ana konusunu oluşturmaktadır. Çalış̧ma alanında yüzlek veren bu tortullar, Acıgöl Grabeni'nin kuzeyinde Oligosen yașlı molas karakterindeki kaba kırıntılı tortulları uyumsuz bir şekilde üzerlemektedir. Pliyo-Kuvaterner yaşlı bu karasal sedimanlar, kahverengimsi kırmızı renkli, kaba kırıntılı çakıltaşı, kumtaşı ve çamurtaşı ara katkılarından oluşan alüvyal yelpaze çökelleri, sarımsı kahverenkli çakıllı kumtaşı ve su altı kayma-oturma yapılarının belirgin olarak gözlendiği kilttașı-silttaşından olușan delta çökelleri ve beyazımsı gri renkli killi kireçtaşları, marn ve travertenlerden oluşan gölsel çökellerden oluşmaktadır. Bu çalışmada, 8 litofasiyes birimi tanımlanmıştır. Çalışma alanının güney kesiminde Acıgöl grabeni'ni sınırlayan KD-GB gidişli düşey atımlı Maymundağı Fayı "Çardak Fayı", GB- Anadolu'daki Neotektonik dönemi yansıtan en belirgin yapısal unsurlardan biridir. $\mathrm{Bu}$ ana faya paralel sintetik ve antitetik faylar sonucu yüzeye ulaşan termal sular, beyaz, masif ve sıkı dokulu, yer yer kırıklı ve çatlaklı traverten oluşumuna neden olmuştur. Ayrıca, bölgede en genç çökeller olarak yüzlek veren alüvyal yelpazelerin yanal ve düşey yöndeki gelişimi, grabeni sınırlayan genç faylar tarafından günümüze dek denetlenmektedir.

\section{The Facies Properties of Plio-Quaternary Terrestrial Sediments in North of the Acıgöl Graben and Palaeoenvironmental Evolution of the Region, SW-Turkey}

\author{
Keywords \\ Lithofacies, \\ Terrestrial deposits, \\ Plio-Quaternary, \\ Acıgöl Graben, \\ SW-Turkey
}

\begin{abstract}
The sedimentological properties and tectono-sedimentary evolution of Pliocene and Quaternary continental deposits which is located at $65 \mathrm{~km}$ 's northeastern of Denizli, constitute the subject of this study. These sediments were disconformably overlie on Oligocene molasse deposits located on the north of Acıgöl graben. These terrrestrial sediments deposited during the Pliyo-Quaternary period consist of brownish, claret coloured, coarse detrital conglomerates, sandstones and mudstones intercalated of aluvial fan deposits, yellowish brown coloured pebbly sandstones, claystones-siltstones with slump structures of deltaic deposits and whitish grey coloured clayey limestones, marls and travertines of lacustrine deposits. In this study, 8 lithofacies units have been described and interpreted. Maymundağı fault "Çardak fault" which is NE-SW trending fault in the south of the study area presents vertical displacement and this fault is one of the significant structural components representing Neotectonic period of the SW Anatolia. The white, massive and compact, locally cracked and fractured travertines were precipitated depending on the thermal water which is up to the surface from syntetic and antitetic faults of the Maymundağ fault. Moreover, the young faults occurring parallel to main fault which bounded graben cut off ancient Quaternary alluvial fan and lateral and vertical developing of the new fans controlled by them till nowadays.
\end{abstract}




\section{Giriş}

Batı Anadolu, Neotektonik dönem boyunca farklı doğrultularda gelişmiş horst ve graben sistemlerinden oluşmaktadır (Şekil 1). Acıgöl grabeni de bu sistemlerinden biri olup, Denizli-Afyon il sınırında, yaklaşık $45 \mathrm{~km}$ uzunluğunda ve $14 \mathrm{~km}$ genişliğinde KD-GB uzanımlı bir grabendir (Şekil 1). Havza KB'da Maymundağı fayı, GD'da Acıgöl fayları ile sınırlıdır. Bölgenin geniş̧leme rejimine bağlı oluşan çöküntü sistemlerinden biri olan bu KD-GB gidişli Acıgöl grabeni, belirgin jeomorfolojik yapısı ve $\mathrm{Na}_{2} \mathrm{SO}_{4}$ 'ca zengin gölüyle birçok araştırmacının ilgi odağını oluşturmaktadır [1, 2]. Grabenin GD'sundaki Acıgöl fayı, Likya naplarına ait kireçtaşı ve dolomitik kireçtaşlarının sınırını oluşturarak belirgin bir morfoloji ile göze çarpmaktadır. Buna karşılık, grabenin KB'sındaki Maymundağı fayı, Paleojen ve Neojen birimlerini kesmekte ancak Acıgöl fayı kadar belirgin bir yüzeylenme sunmamaktadır. Grabenin KB'sındaki Maymundağı 1689m (Domuz T.) ve GD'sundaki Yandağ'ın yükseltisi 2033m'dir. Graben havzasını sınırlayan Maymundağı yükseltisi Oligosen yaşlı Çardak formasyonu ile temsil edilmektedir. Bu birim, başlıca kumtaşı ve çamurtaşı ara düzeyleri içeren çakıltaşlarından oluşmaktadır. Gabenin GD'daki yükselim alanlarında ise bölgeye Kampaniyen'de yerleşen allokton konumlu ofiyolit, ofiyolit karmaşığı ve Mesozoyik karbonatları yüzeylemektedir. Bölgede yapılan jeomorfolojik veriler ışığında, graben havzasının GD kenarı boyunca, KB kenarına oranla daha yüksek bir sübsidansın olduğu belirtilmiştir [3].

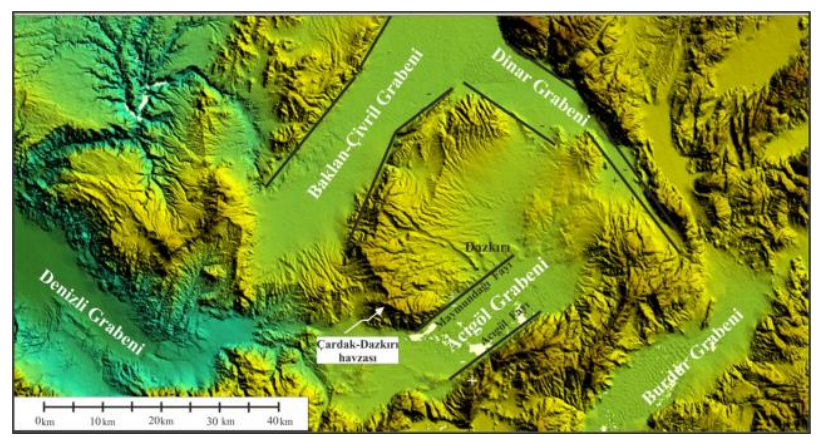

Şekil 1. KD-GB uzanımlı Acıgöl grabeni ve onu sınırlayan Acıgöl fayı ve Maymundağı fayının uydu görüntüsü. Grabene paralel gelişen Burdur ve Baklan-Çivril grabenleri ve bu grabenleri kesen Denizli ve Dinar grabenleri

Acıgöl grabeni ile ilgili olarak bugüne kadar yapılan çalışmalar, genellikle gölün hidrolojisi, grabenin tektonik yapısı ve kuzeyindeki birimlerin tektonosedimanter özelliklerini içermektedir [1-6].

Göktaş vd. [4] bölgede yaptıkları çalışmada, çalışma alanı içinde yer alan gölsel karakterdeki Pliyosen yaşl birime, Hasandede grubu ismini vermişlerdir. Bunun yanısıra, Acıgöl grabeninin kuzeyinde yüzeyleyen ve litoloji benzerliğinden dolayı karasal bu birim, Çameli formasyonu olarak adlandırılmış [7] ve bu formasyon, Kızılören üyesi, Çamurtaşı-marn üyesi ve Kireçtaşı üyesi olarak üçe ayrılmıştır (Şenel, 1997).

Sözbilir [8] çalıșmasında, Likya napları tarafından bağlantıları kesilen Kale-Tavas, Denizli ve ÇardakDazkırı havzalarını ayrıntılı olarak incelemiștir.

Alçiçek vd. [9] Çameli havzasında yapmış olduğu çalışmada, havzanın Geç Miyosen'de KD-GB uzanımında bir graben olarak açılmaya başladığını ve Erken-Orta Pliyosen'de büyük bir faylanma ile havzanın ikiye ayrıldığından sözetmișlerdir. Gölsel tortullarla karakterize edilen Çameli Havzası'ndan elde edilen memeli bulguları, Orta-Geç Pliyosen yaşlarını vermiştir. Çameli formasyonu olarak adlandırılan bu birim, alttan üste doğru; sırasıyla alüvyon yelpazesi, akarsu ve gölsel depolanma sistemlerini temsil eden, Derindere üyesi, Kumafşarı üyesi ve Değne üyesi olarak ayırmışlardır. Ayrıca havzanın gelişimi ve depolanma ortamlarındaki değişiklikler, bu çalışmada detaylı olarak incelenmiștir.

Helvacı vd. [10] Acıgöl havzasında yaptıkları sondaj verilerine göre, Acıgöl grabenini denetleyen aktif sintetik ve antitetik faylar sonucunda gölün kademeli olarak kalıcı derin bir göl ortamından geçici sığ playa tipi bir göle geçiş gösterdiğini vurgulamışlardır.

Toker [11,12] Sarıkavak-Dazkırı bölgesinde yaptığı çalışmada, Çameli Formasyonu'nun üst kesimlerinde, tektonik hareketlenmeye bağlı olarak, karbonatça zengin sıcak su çıkışları sonucu çökelen travertenlerin U/Th yöntemine göre orta Pleyistosen döneminde çökeldiğini belirtmiştir. Kuvaterner çökellerinden elde edilen radyometrik yaşlar ve duraylı izotop verileriyle bölgenin paleoiklimsel değişimlerine ışık tutulmaya çalıșılmıştır [12].

$\mathrm{Bu}$ çalışmada, Neotektonik dönemde Acıgöl grabeninin gelişimiyle eş yaşlı olarak çökelen Pliyosen yaşlı Çameli formasyonu ve onun üzerine gelen Kuvaterner yaşlı karasal çökellerin depolanma süreçleri ayrıntılı olarak incelenmiş, birimlerin lithofasiyes tanımlamaları ve fasiyes ilişkileri ortaya konmaya çalışılmıştır. Buna ek olarak, PliyoKuvaterner yaşlı bu karasal tortullar diğer benzer havzalarla karşılaştırılarak yorumlanmaya çalışılmıştır.

\section{Bölgenin Stratigrafisi}

Batı Anadolu'da gelișen Tersiyer havzaları, neotektonik dönemden önce KD-GB uzanımlı bir tek havza olup, günümüzde aynı hat üzerinde birbirleriyle bağlantıları temel yükseltilerle kesilmiştir [5]. Bu havzalar, bölgenin güneybatısında yeralan Kale-Tavas havzası ile hemen doğusunda yeralan Denizli ve Çardak-Dazkırı havzalarıdır ve doğudan batıya doğru gençleşerek çökelmişlerdir [5] (Şekil 2). Paleojen-Neojen yaşlı çökeller, kuzey- 
kuzeybatı yönünden bölgeye yerleşen Likya naplarının üzerinde uyumsuz olarak depolanmışlardır. Çalışma alanı içinde bulunan, Çardak- Dazkırı havzası, Acıgöl grabeni'nin kuzeyinde çökelen, erken Oligosen (Rupeliyen) yaşıyla bölgedeki en yaşlı Tersiyer havzası olarak bulunmaktadir $[5,13]$.

Oligosen dönemi, GB Anadolu'da büyük çaplı ofiyolit nap yerleşimlerinin devam ettiği ve bindirme tektoniğine bağlı olarak bölgesel yükselmelerin egemen olarak geliştiği bir zaman aralığını simgeler [14]. Genel olarak, Çardak ve çevresini de içine alan GB-Anadolu bölgesinde yükselen dağ kuşaklarının çoğunlukla güneyinde ve batı bölümlerinde Oligosen döneminde ortaya çlkan havzalarda molas tipinde oldukça kalın ve kaba kırıntılı tortullar depolanmıştır $[15,16]$. Çardak ve Dazkırı molası olarak tanımlanmıș olan kaba kırıntılı bu tortullar, batıda yer alan KaleTavas ve Denizli havzalarının devamı olarak düşünülebilir (Şekil 2). Batı Anadolu'da çekme tektoniğine bağlı olarak farklı doğrultularda gelişen normal faylar, bu havzaları birbirinden uzaklaștırarak üç parçaya ayırmıștır. Her bir parça farklı isimler alarak Muğla'dan Dazkırı'ya kadar bir hat boyunca günümüzdeki konumuna sahip olmuştur [17].

Bölgedeki genişleme rejimi altında birbirleriyle olan ilișkileri tamamen kopmuş olan bu havzalardaki tortullar, genellikle kaba taneli, kalın-çok kalın, yer yer masif bir görünüm sunan, çoğunlukla kireçtaşı ve ofiyolit parçalarından türemiş, iyi yuvarlaklaşmış, tane destekli çakıltaşlarından oluşmuşlardır.

\subsection{Paleojen çökelleri}

Paleojen yaşlı birimler, çalışma alanı ve çevresinde, Likya naplarının üzerine uyumsuz olarak gelen kalın bir istiften oluşmaktadır (Şekil 2). Likya naplarını oluşturan kaya birimleri, Baklan ilçesinin doğusunda Baklan grabenini sınırlayan, genellikle kahverengimsi sarı, kirli sarı ve yeşilimsi gri renklerde metakonglomera, kuvarsit, kuvarsitşist, şist gibi metamorfik kayaçlardan oluşan Alt Triyas yaşlı Karaova Fm. [18, 19] ile masif, orta-kalın tabakalı, siyahımsı gri, yer yer açık gri renkli dolomit ve dolomitik kireçtaşlarından oluşan Kayaköy Dolomitinden oluşmaktadır [19].

Çalışma alanında Likya naplarının üzerine uyumsuz olarak, çakıltaşları ve kumtaşlarından oluşan, ortageç Eosen yaşlı Başçeşme Formasyonu gelmektedir $[4,20]$. Acıgöl Grubuna ait bu Oligosen tortulları, Acıgöl'ün kuzey kesiminde yüzlek vermekte ve molas karakterinde kalın katmanlı çakıltaşı-kumtaşı ve çamurtaşı bileşenlerinden oluşmaktadır [21] (Şekil 3). Acıgöl grubu, alttan üste doğru; Armutalanı, Çardak, Hayrettin, Tokça ve Bozdağ olmak üzere beş formasyona ayrılmıştır [4]. Eosen yaşlı Başçeşme formasyonu ve üzerine uyumsuz olarak gelen Oligosen yaşlı Acıgöl grubu, genellikle karasal ve yer yer sığ denizel ortamlarda depolanmış çökellerdir. Bu çökellerin üzerine, Pliyosen yaşlı Çameli formasyonu uyumsuz olarak gelmektedir [4].

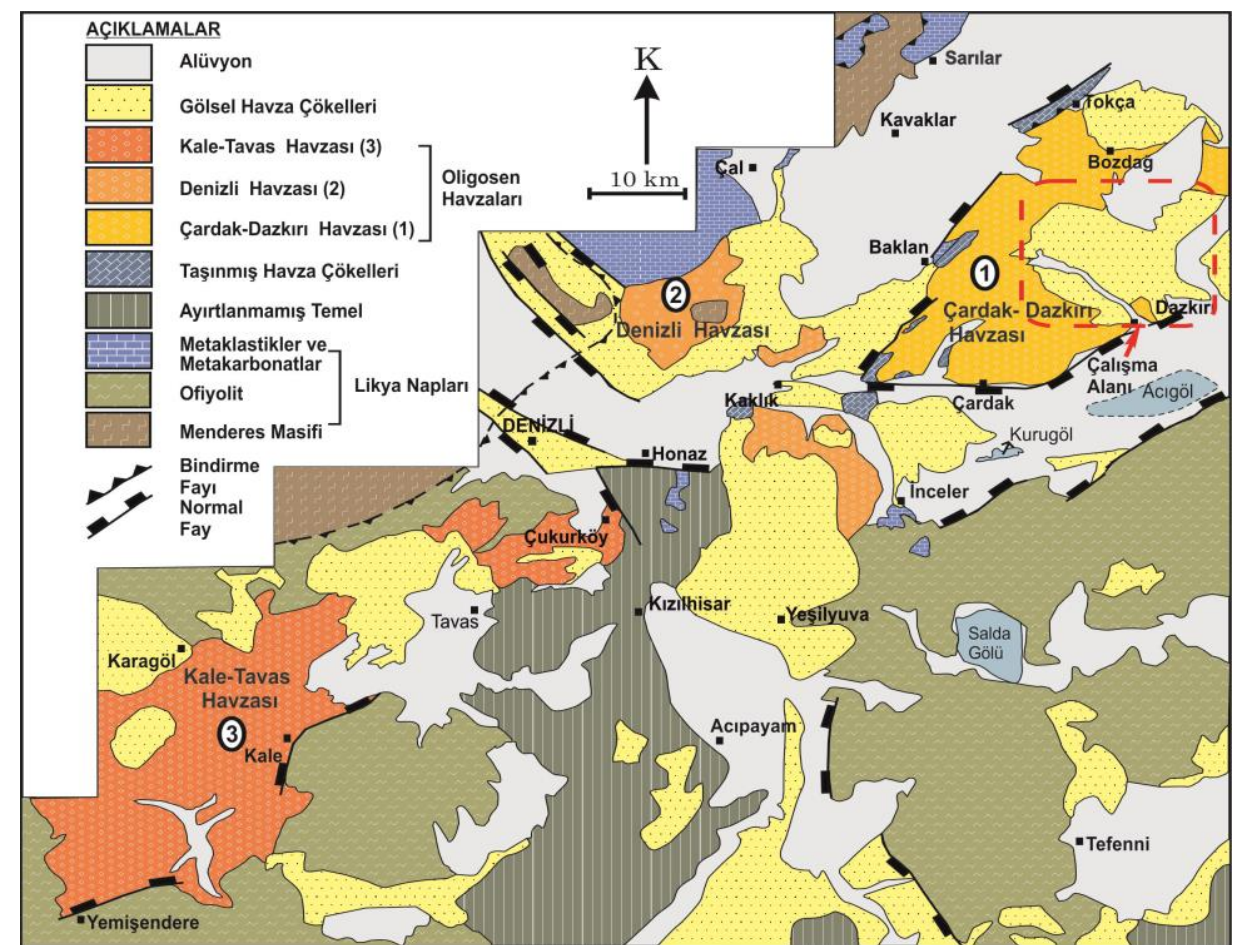

Şekil 2. GB Anadolu'daki Oligosen havzalarını gösteren basitleştirilmiş jeoloji haritası ve Pliyosen yaşlı gölsel tortullardan oluşan çalışma alanı ([5,6,7]'den değiștirilerek hazırlanmıştır) 


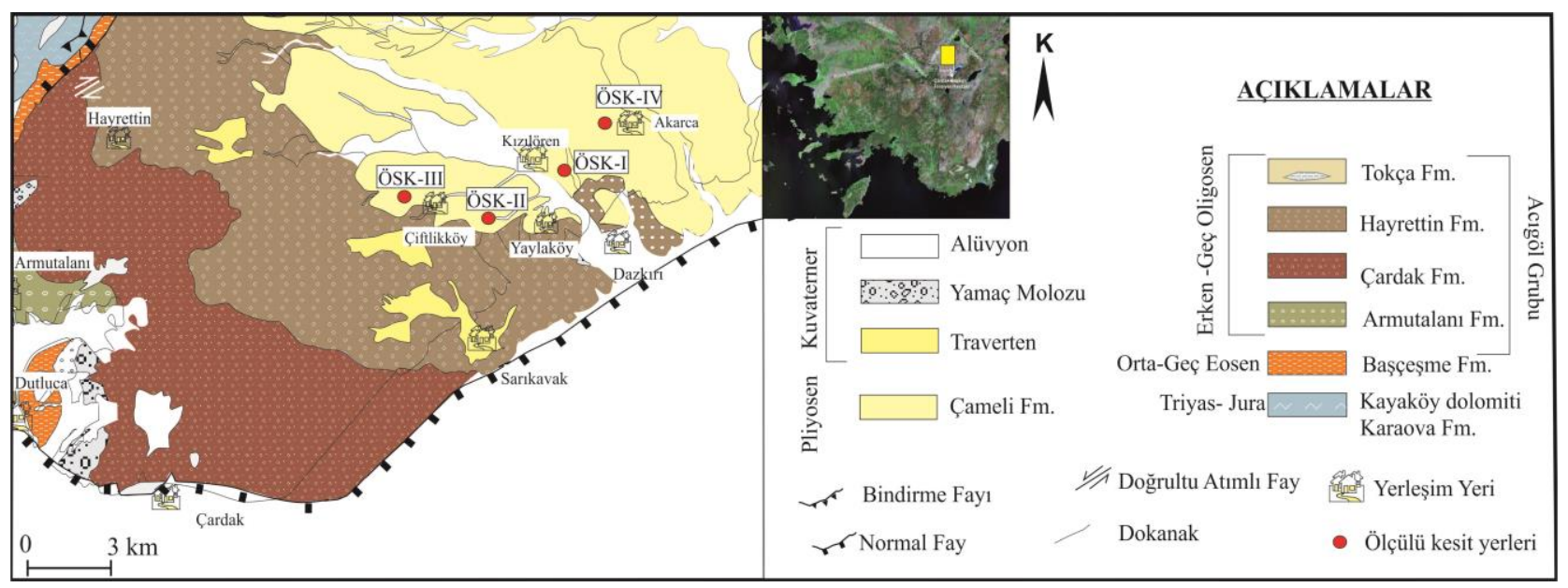

Şekil 3. Çardak-Dazkırı Havzasında yer alan litostratigrafik birimlerin jeolojik haritası ve ölçülü stratigrafik kesitlerin lokasyon yerleri ([7]'den değiștirilerek hazırlanmıștır)

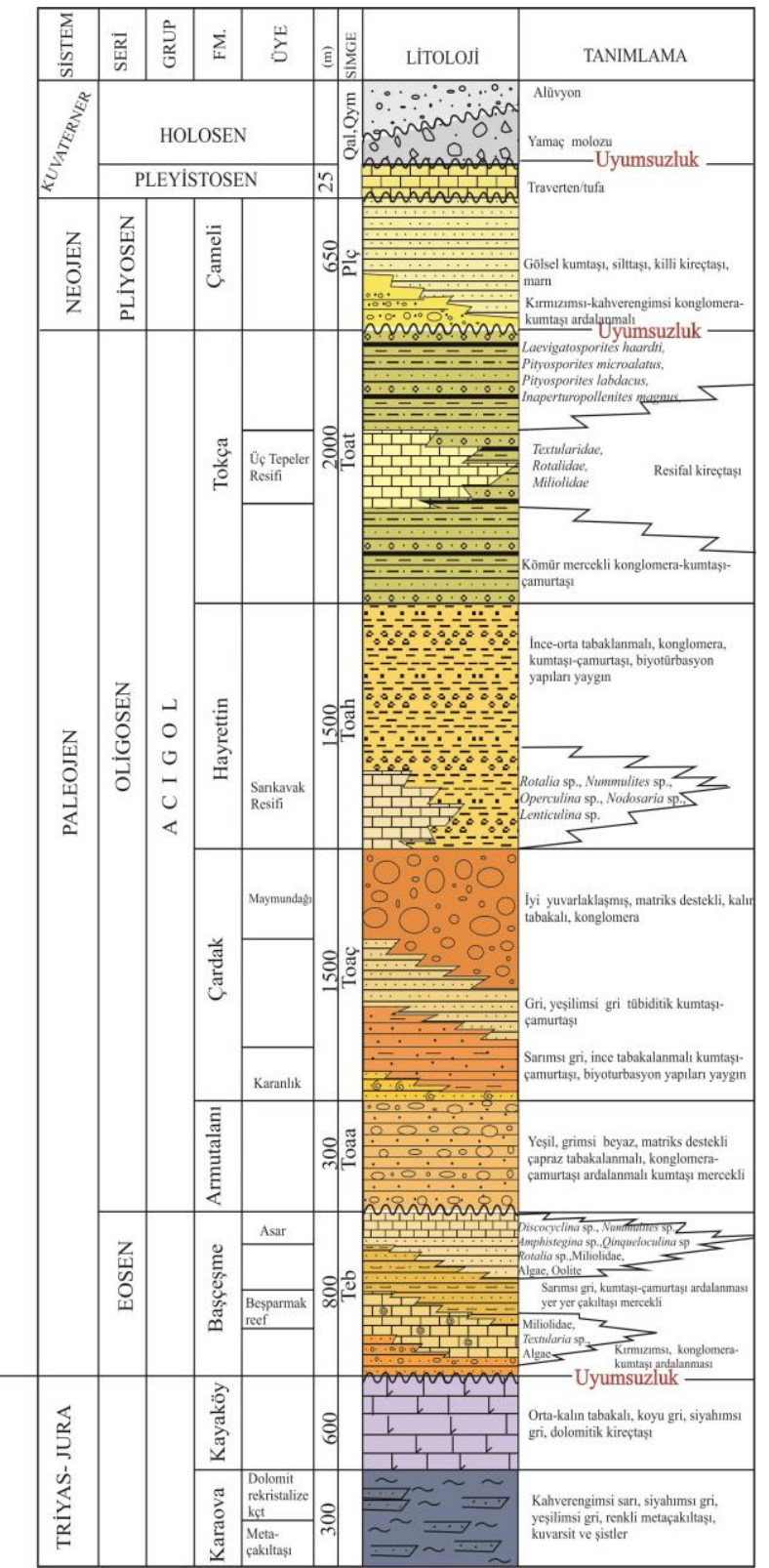

Şekil 4. Çalıșma alanının genelleștirilmiş stratigrafik sütun kesiti (7'den değiștirilerek hazırlanmıștır)

\subsection{Neojen çökelleri}

\subsubsection{Pliyosen birimleri (Çameli formasyonu)}

Dazkırı ilçesinin kuzey ve kuzey batısında, ayrıca Baklan Graben havzasında Paleojen tortul istifinin üzerine, genellikle ince ve kaba kırıntılılardan oluşan Çameli Formasyonu uyumsuz olarak gelmektedir [22]. Bu formasyon, Denizli'nin güneyindeki Çameli ilçesinde gözlenen gölsel karakterdeki ince kırıntılılar için de kullanılmıştır [9]. Bu formasyon, Acıgöl grabeninin güney kesiminde geniş bir alanda yayılım göstermesine rağmen grabenin kuzey kesiminde sadece Dazkırı, Kızılören ve Akarca köylerinde tipik olarak gözlenmektedir (Şekil 3). Formasyonu oluşturan tortullar, kahverengimsi sarı, beyazımsı sarı renkte olup, egemen olarak çakıltaşı, kumtaşı, çamurtaşı, killi kireçtaşı birimlerinden oluşmaktadır (Şekil 4). Çalışma alanındaki kalınlı̆̆ toplam 1000m'ye ulaşmaktadır.

\subsubsection{Kuvaterner birimleri}

Çalışma alanı ve çevresinde, Kuvaterner birimleri, killi kireçtaşı ve traverten/tufa gibi karasal karbonatlardan, dolgu tortullarından ve genç alüvyal yelpazelerden oluşmaktadır (Șekil 4). Yapılan önceki çalışmalarda traverten, tufa gibi karasal karbonatların çökelme yaşı, stratigrafik konumundan dolayı Pliyosen yaşlı Çameli formasyonuna dahil edilmiştir [7]. Ancak traverten ve tufa çökelleri üzerinde yapılan ayrıntılı sedimantolojik çalışmalar sonucunda Acıgöl Grabeni kuzeyinde (Sarıkavak köyü) yer alan karasal karbonatların orta-geç Pleyistosen yaşında olduğu bulunmuștur [23]. Bu bölgede yüzeyleyen karasal karbonatlar, yer yer hidrotermal çıkışların olduğu traverten çökelleri ve graben kenarına doğru akış yönüne sahip dere yatakları boyunca ortam sıcaklığında çökelen, bol gözenekli, organik maddece zengin tufa oluşumlarıdır [23]. 
Kuvaterner (Holosen) çökelleri, Acıgöl Graben'inin KB'sında alüvyal yelpazeleri olarak yüzlek verirken, GD kenarında kolüvyon konileri şeklinde belirgin bir morfoloji sunmaktadır $[6,8,10]$.

Grabenin kuzey kenarında yüzlek veren alüvyal yelpazeler, Maymundağı'nın Acıgöl'e bakan yamaç tabanlarında çok sayıda birbirine girik şeklinde gözlenmektedirler. Alüvyon yelpazeleri kuzeydeki Oligosen yaşlı Çardak Formasyonu'na ait ofliyolitik kayaçlardan türemiş çakıltaşlarından beslenmiştir.

Son yıllarda, Çardak- Dazkırı arasındaki yol yapım çalışmaları sırasında bazı alüvyon yelpazeleri kazılmış ve böylece iç yapıları ortaya çıkmıştır. Birbiri ile yanal yönde girişim yapan yelpazelerin boyları 20 ile $40 \mathrm{~m}$ arasında değişir. Çardak ilçe merkezine yakın bazı yelpazelerin kazı yüzeylerinde açlk renkli volkanik kül ara düzeyleri görülmektedir.

\section{Bulgular}

İnceleme alanında gözlenen Pliyo-Kuvaterner yaşlı tortulların litofasiyes özellikleri, fasiyes birlikleri ve çökelme koşulları ayrıntılı olarak çalışılmıştır. Bu amaçla, depolanma ortamlarını iyi karakterize eden, tortul çökellerinin net bir şekilde gözlendiği lokasyonlardan ölçülü stratigrafik kesitler alınmıştır (Şekiller 6 ve 7). Arazide yapılan, ayrıntılı sedimantolojik çalışmalar ve elde edilen ölçülü stratigrafik kesitler sonucunda, çalışma alanındaki Pliyo-Kuvaterner yaşlı birimlerin litofasiyesleri belirlenerek depolanma süreçleri ve ortamları hakkında önemli ipuçları elde edilmiştir. $\mathrm{Bu}$ çalışmada yapılan fasiyes tanımlamaları Miall'ın çalışması [24] temel alınarak hazırlanmıştır.

\subsection{Pliyosen tortullarının litofasiyes özellikleri}

Matriks destekli çakıltaşı fasiyesi (F-1): Sarımsı kahverengi renkli yer yer kiremit kırmızısı renginde, çoğunlukla matriks (hamur) destekli bağlayıcıya sahiptir. Fasiyes içerisindeki çakıllar, genellikle ofiyolitik kayaç parçalarından ve kireçtaşlarından türemişlerdir. Çakıllar, orta-kötü yuvarlaklaşmış ve sıkı tutturulmuşlardır. Tane boyları maksimum $40 \mathrm{~cm}$ blok boyutuna varan bloklar içermektedir. Aşınmalı bir tabana sahip bu çakıltaşları içinde herhangi bir katmanlanma ve iç yapı gözlenmemektedir (Şekil 6a). Biyoturbasyon izlerine ve fosil bulgularına bu fasiyes içinde rastlanılmamıştır. Çakıltaşlarında kırmızımsı rengin egemen olması, hiçbir fosil bulgularına ve biyortubasyon izlerine rastlanılmaması, bu çökellerin karasal bir ortam ürünü olduğuna işaret etmektedir. Çakıltaşları içinde boylanmanın kötü olması, çakıltaşı-kumtaşı oranının 1'den büyük olması ve çakıltaşlarının aşınmalı (erozif) bir tabana sahip olmaları ortamın enerjisinden kaynaklanmaktadır. Fasiyesin karmaşı bir yapı sunması ve herhangi bir sedimanter yapı sunmaması, birimin kütlesel hareketlere bağlı olarak hızlı bir şekilde, kaynağa yakın bir yerde depolanan moloz akma çökelleri olduğunu göstermektedir.

Çapraz tabakalanmalı kumtaşı fasiyesi(F-2): $\mathrm{Bu}$ fasiyes, egemen olarak sarımsı kahverengi, kırmızımsı renkli, tane destekli kumtaşları ve ince çakıltaşlarından oluşmaktadır. Birim, hemen hemen yatay konumlu veya çok düşük açılı $\left(\sim 6^{\circ}\right)$, çapraz katmanlanmalıdır. Kızılören Köyünde tipik olarak gözlenen bu fasiyes, altta bulunan kırmızı renkli çakıltaşlarının yanal devamı şeklinde gözlenmektedir. İnce-orta tabakalı kumtaşları, çapraz katmanlanmalı, orta- kötü boylanmalı ve iyi tutturulmamıștır (Şekil 6a). Çapraz katmanlı bu kumtaşları genellikle aşınmalı bir tabana sahiptir. Kumtaşları içinde herhangi bir fosil bulgusuna ve canlı izine rastlanılmamıştır. Kumtaşları ile ardalanmalı olarak bulunan çakılttaşları genellikle orta-iyi boylanmalı, iyi yuvarlaklaşmış ve iyi tutturulmuştur. Kumtaşıçakıltaşı oranı 1'den küçüktür. Çakıltaşları içinde de çok fazla belirgin olmayan küçük çapraz katmanlanmalar gözlenmektedir. $\mathrm{Bu}$ fasiyese ait tortullarda kırmızı renk en önemli ayırtmanlardan biridir ve bu fasiyese ait birimlerin karasal ortamda çökelmiş olduğunu göstermektedir. Ayrıca kumtaşlarında yaygın olarak görülen çapraz katmanlanma, enerjinin çok düşük olmadığına işaret etmekte ve bu çapraz tabakalı kumtaşı birimi, alüvyal yelpazenin ortaç kesimini yansıtmaktadır.

Paralel laminasyonlu çakıllı kumtaşı fasiyesi ( F-3): $\mathrm{Bu}$ fasiyes, açık kahverengimsi renkte, çakıltaşları ve kumtaşlarından oluşmaktadır. Kumtaşları, paralel laminasyonlu olup, içlerinde $\mathrm{mm}$ boyutunu geçmeyen çakıl mercekleri belirgin olarak gözlenmektedir (Şekil 6b). Çakıltașları, iyi yuvarlaklașmıș, orta-kötü boylanmalı ve bol kırıklı çatlaklıdır. Çakıllar, karbonat çimentolu ince kumtaşlarından oluşan matriksle tutturulmuşlardır. Çakıltaşları, kireçtaşı ve ofiyolitik kaya kırıntılarından türemişlerdir. Çakılların tane boyu, birkaç mm'den başlayıp 10cm'ye kadar değişmektedir. Çakıllarda herhangi bir iç yapı gelişmemiştir. $\mathrm{Bu}$ fasiyese ait tortulların, yüksek yoğunluklu akışın egemen olduğu bir ortamda çökelmiş olma olasılığı yüksektir. Ancak çakıllı kumtaşlarında gözlenen paralel laminasyon yapısı, akışın ara ara belli bir hızda sabitlenerek devam ettiğini göstermektedir. Fasiyese ait çökeller, transgresif bir aşmayla havza kenarlarında depolanmış, kalıntı çökelleri (lag deposit) olarak düşünülebilir. Delta üstü (düzlüğü) tortulları genellikle temiz kumlardan oluşur ancak kanallarda gecikme çökeli tortulları bulunabilir. Fasiyeste görülen bu çakıllar da, kanallarda bulunan tortullara işaret etmektedir.

Deformasyon yapılı kiltaşı-çamurtaşı fasiyesi (F-4): Bu fasiyese ait çamurtaşları, gri, mavimsi gri renkte, ince- orta tabakalıdır. Çamurtaşları içinde deformasyon yapıları belirgin olarak gözlenmektedir (Şekil 6b). Silttaşları, sarımsı kahverengi renkte, 
ince-çok ince tabakalıdır. Silttaşı içinde kaymaoturma yapıları oldukça belirgindir. Silttaşıçamurtaşı fasiyesinin üzerine açık kahverenkli, hemen hemen yatay konumlu, ince-orta tabakalı, normal derecelenmeli, amalgasyon izleri belirgin, yer yer mercek şeklinde çakıllı seviyelerin görüldüğü, kırıklı çatlaklı kumtaşları gelmektedir. Herhangi bir fosil içeriğine rastlanılmayan bu deformasyon yapılı (oturma-kayma) ince taneli tortulların, delta önü (prodelta) ortamını yansıttığı düşünülmektedir. Silttaşı-çamurtaşı birimlerinde görülen kaymaoturma yapısı, ortamın yamaç duraysızlığı nedeniyle su içi kütle hareketleri sonucunda gelişmiştir.

Biyoturbasyonlu kiltaşı-marn fasiyesi (F-5): Yanal yönde yüzlerce metre devamlılığı olan paralel laminanlanmalı beyaz renkli killi karbonat ve marnlardan oluşan bu birim, yapısal deformasyon nedeniyle yer yer bol kırıklı olarak göze çarpmaktadır. Marnlar genellikle az tutturulmuş ve dağılgandır. Kiltaşları içinde paralel tabakalanma ve yer yer biyoturbasyon izlerine rastlamak mümkündür. Havzanın ortalarına doğru karbonat miktarında bir artış görülmektedir. Bu fasiyese ait tortullar, asılı halde bulunan, akıntı enerjisinin oldukça düşük olduğu bir göl ortamının çökelleri olduğu düşünülmektedir.

\subsection{Kuvaterner tortullarının litofasiyes özellikleri}

Laminalı traverten (F-6): Bu fasiyes, beyazımsı bej, sarımsı gri renkli, paralel laminalı, masif görünümlü travertenden oluşmaktadır. Arazide belirgin bir görünüm sunan bu birimin ölçülü stratigrafik kesitlerde yaklaşık 10 metre görünür kalınlığa sahiptir. Travertenlerde açlma tektoniği sonucu faylara bağlı olarak gelişen kırık ve çatlak sistemleri mevcuttur. Kalsit dolguları oldukça yaygındır ve iç yapısız, organik maddece zengin çamurtaşı seviyeleri (F-9) görülmektedir. Faylara bağlı olarak sıcak su çıkışları sonucu oluşmuş bu traverten fasiyesi, gölsel kırıntılılarla (F-5) yanal geçişlidir. Travertenlerin kalınlıkları, traverten seviyesini ve oluşumlarını denetleyen bu faylardan uzaklaştıkça azalmakta ve gölsel marn, killi kireçtaşı birimine geçiş göstermektedir. Buna ek olarak, sadece lokal olarak Sarıkavak Köyü'nde yüzlek veren tufa çökelleri, karbonatça zengin, ortam sıcaklıklı̆̆ında, akarsular boyunca taşınan, stromatolit, fitoklast, briyofit ve makrofitlerin yoğun olarak gözlendiği karasal karbonatlar olarak bulunmaktadır [11]. Ancak bu çalışmada, incelenen lokasyonlarda sadece traverten çökelleri görülmüştür ve herhangi bir tufa oluşumuna rastlanılmadığı için tufa lithofasiyesleri belirlenememiştir.

Biyomikritik traverten (F-7): Traverten birimi içinde, mikritik dokuya sahip, pelloidal görünümlü, algal oluşuklar gözlenmektedir (Şekil 5). Pelloidal görünüme mikritik malzemenin suyunu kaybedip kuruması ve topaklanması sebep olmaktadır. Boşluklar sparikalsit dolguludur. Boşlukların kenarından merkeze doğru sparikalsit kristallerinin boyu irileşmektedir. Alglerin oluşturduğu boşluklar yoğun şekilde görülmektedir. Bazı alglerin içyapıları da sparitle doldurulmuştur. Mikritik malzemenin esas kökeni alglerdir. Parçalanmış organik madde kalıntıları yersel olarak görülmektedir. İncelenen traverten örnekleri, (25)'ye göre algal biomikrit, (26)'e göre tanetaşı olarak adlandırılabilir. Oluşum ortamı olarak bu sıkı dokulu traverten fasiyesi için, göl kenar seviyelerindeki faylara bağlı olarak gelişen su çıkışları sonucu oluştuğu söylenebilir.

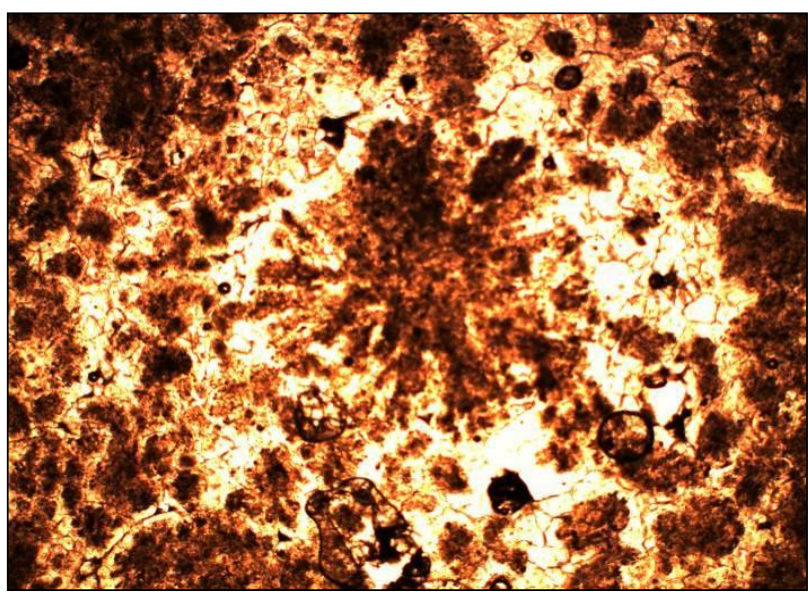

Şekil 5. Biyomikritik traverten fasiyesine ait ince kesit örneği. Alglerin traverten içindeki mikritik dokusu

Paleosol (F-8):Bu fasiyes, kahverengimsi gri renkli, organik maddece zengin, yaklaşık $60 \mathrm{~cm}$ kalınlığında çamurtaşlarından oluşmaktadır. Laminalı traverten fasiyesinin (F-6) üst kesimlerinde görülmektedir. Paleosol seviyeleri, traverten çökeliminin durduğu veya çeșitli sebeplerle (sıcak su gelimindeki azalma veya iklimsel değişimler) duraksadığı dönemlerde, çevreden gelen silt, kil gibi kırıntılıların depolanması sonucu olușur.

\subsection{Fasiyes birlikleri}

\subsubsection{Alüvyal yelpaze çökelleri}

Çameli formasyonunun taban kesimlerinde gözlenen ve egemen olarak çakıltaşı-kumtaşı-çamurtaşı ardalanmasından oluşan bu tortullar, matriks destekli çakıltaşı fasiyesi (F-1) ve çapraz tabakalanmalı kumtaşı fasiyesinde (F-2) görülmektedirler (Şekiller 6 ve 7 ) (Tablo 1). Kırmızımsı, kahverengi renkte yüzeyleyen kaba kırıntılı bu çökeller, Kızılören Köyü ve çevresinde tipik olarak gözlenmektedir. Kızılören üyesinde yer alan alüvyal yelpaze çökelleri, yelpazenin yakınsak ve ortaç kesimlerini karakterize eden tortul yapılar sunmaktadır (ÖSK-I) (Şekil 6a). Beyaz renkli, killi kireçtaşı gibi gölsel çökeller, kırmızı rengin egemen olduğu ve herhangi bir canlı izine rastlanmayan alüvyal yelpaze tortullarıyla yanal yönde geçiş göstermektedir. 
ÖSK-I (Kızlören Kesiti)
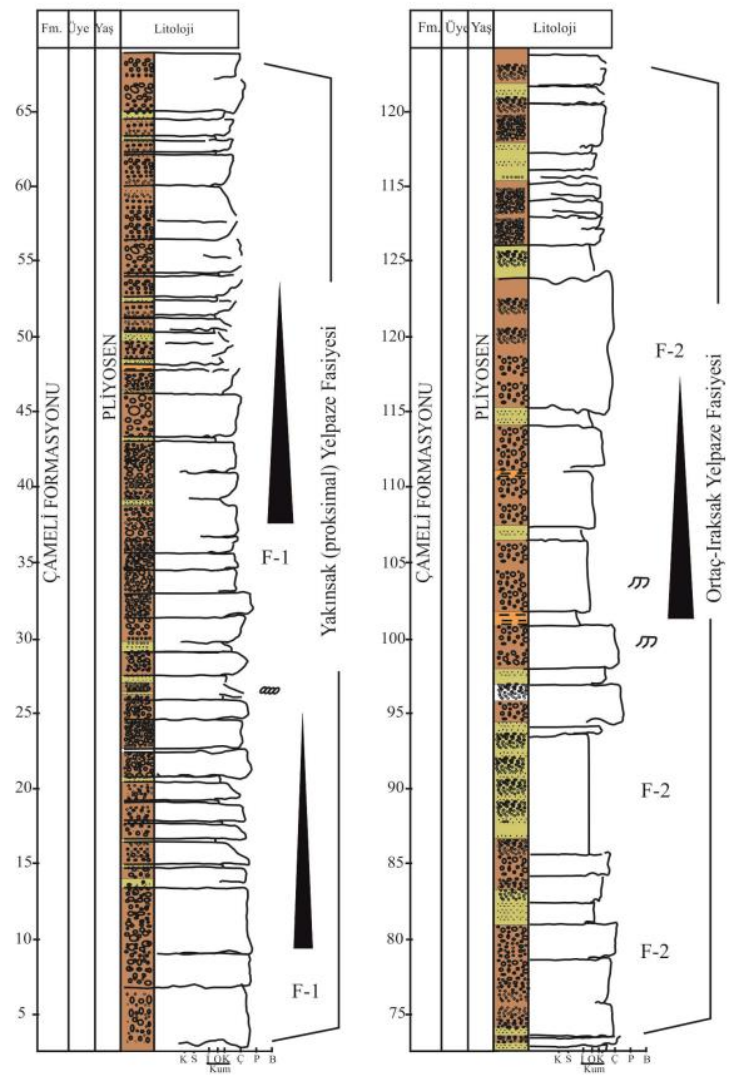

ÖSK-II (Yaylaköy Kesiti)

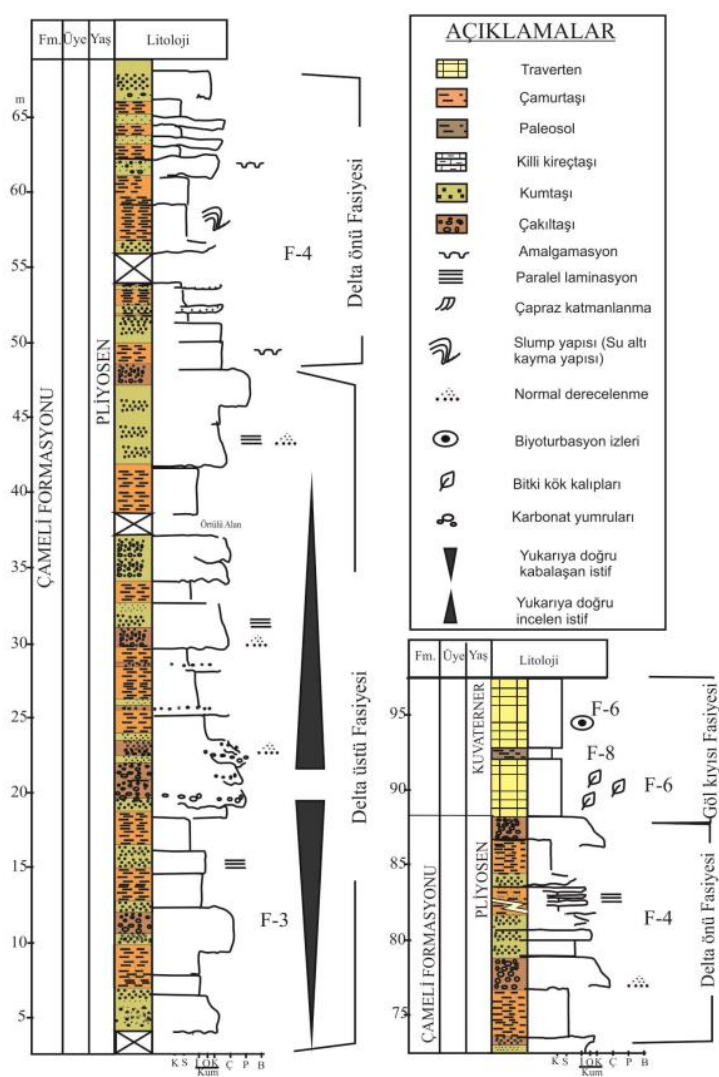

Şekil 6. Çalışma alanında yer alan Kızılören (ÖSK-I) ve Yaylaköy (ÖSK-II) mevkilerinden alınan Pliyosen ve Kuvaterner çökellerine ait ölçülü stratigrafik kesitler (Kesit yerleri için Şekil 3'e bakınız)

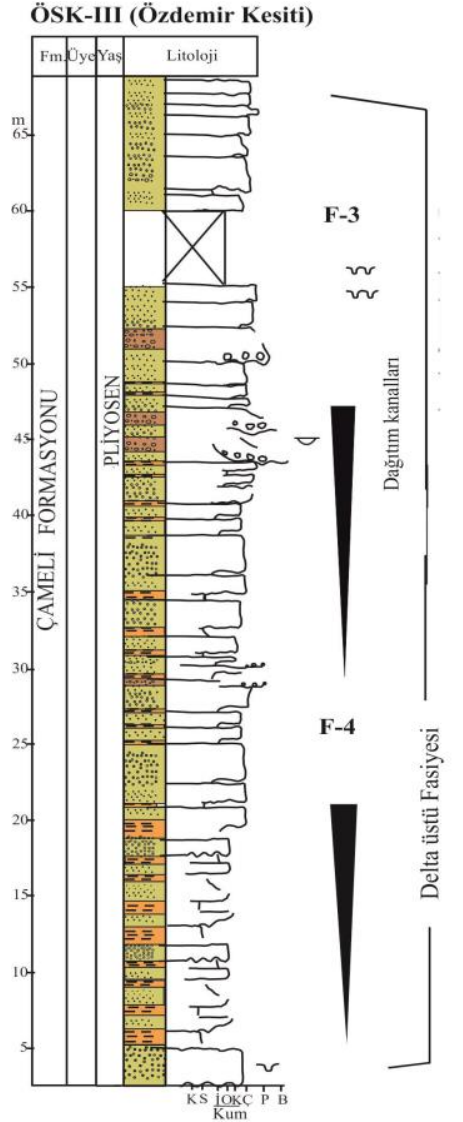

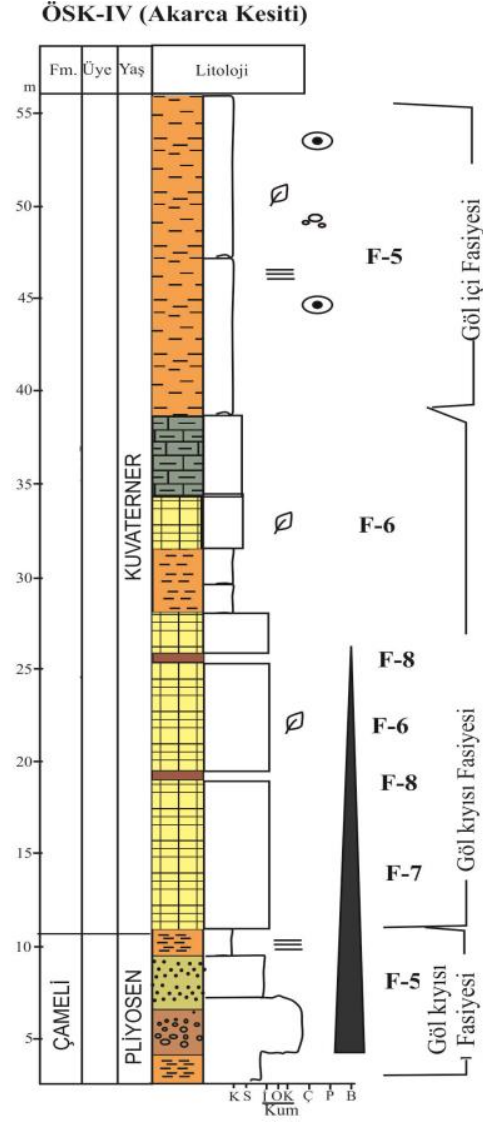

(b)

Şekil 7. Çalışma alanında yer alan Özdemir (ÖSK-III) ve Akarca (ÖSK-IV) lokasyonlarından alınan Pliyosen ve Kuvaterner çökellerine ait ölçülü stratigrafik kesitler (Kesit yerleri için Şekil 3'e bakınız) 


\subsubsection{Delta çökelleri}

Pliyosen yaşlı kahverengimsi kırmızı renkli çakıltaşıkumtaşlarının üzerine gelen delta çökelleri, paralel laminasyonlu çakıltaşı-kumtaşı fasiyesi (F-3) ve deformasyon yapılı çamurtaşı-kumtaşı fasiyesinden (F-4) oluşmaktadır (Şekiller 6 ve 7) (Tablo 1). Gri renkli, sarımsı gri renkli bu ince taneli kırıntılılar, özellikle Çiftlikköy ve Sarıkavak Köylerinde tipik olarak gözlenmektedir (Şekil 8b). Bu çökeller, su altı kayma-oturma yapılarının görüldüğü ince taneli kırıntılılar ile kalıntı çökelleri olarak tanımlanan çakıllı kumtaşları ile temsil edilmektedir (ÖSK-II) (Şekil 8b). Delta çökelleri, Çameli formasyonunun Kızı̈ören üyesi içinde görülen alüvyal yelpaze çökellerinin devamı şeklinde yorumlanabilir. Killi kireçtaşı, marn ve travertenler ile temsil edilen gölsel çökeller, delta çökellerinin üzerine gelmektedir (Şekil 8c-d).

Delta çökellerinin, delta üstü ve delta önü çökelleri olarak iki alt ortamlarda depolanmış olduğu söylenebilir. Delta üstü tortulları, özellikle Sarıkavak Köyü ve çevresinde tipik olarak gözlenmekte olup genellikle paralel laminasyonlu çakıllı kumtaşlarından oluşmaktadır (ÖSK-II). Bu kumtaşları üzerine gelen traverten çökelleri, altında bulunan diğer birimlerin katmanlanma yapısını bozmuştur. Delta önü çökelleri, yerçekimine veya tektonik hareketlenmeye bağlı olarak gelişen kaymaoturma deformasyon yapılarının görüldüğü silttaşıçamurtaşı tortulları, özellikle Çiftlikköy Köyü'nün doğusunda, Yaylaköy kesitinde belirgin olarak gözlenmektedir (ÖSK-II) (Şekil 6).

\subsubsection{Göl çökelleri}

Çameli formasyonu içinde gözlenen karbonatça zengin gölsel çökeller, biyoturbasyonlu kiltaşı-marn fasiyesi (F-5), Laminalı traverten (F-6), Biyomikritik traverten (F-7) ve Paleosol (F-8) fasiyeslerinden oluşmaktadır (ÖSK-IV) (Şekiller 6 ve 7) (Tablo 1). Karbonat çökellerinin egemen olarak bulunduğu bu tortullar, özellikle Akarca ve Sarıkavak Köylerinde tipik olarak görülmektedir (Şekil 8d). Göl çökelleri; bej renkli, sıkı dokulu masif traverten fasiyesi ve beyaz renkli kiltaşı-marn fasiyesi olmak üzere iki kısımda incelenmiştir. Beyaz renk dağılımının baskın olarak görüldüğ̈̈ marnlı seviyeler, Akarca Köyü ve çevresinde yoğun olarak gözlenmektedir. Bundan dolayı, Akarca Köyü ve çevresi, Pliyosen dönemindeki göl havzasının orta kesimlerine denk geldiğini söylemek mümkündür. Traverten fasiyesi, Hayrettinköy Köyü'nün doğusunda ve Sarıkavak Köyü'nde yüzlek vermektedir [6,11]. Traverten fasiyesine ait tortullar, kalıntı çökelleriyle beraber Hayrettin formasyonun üzerine uyumsuz olarak gelmektedir.

Göl tortullarını; göl kıyısı çökelleri ve göl içi çökeller olarak ikiye ayırmak mümkündür. Buna göre göl kıyısı (kenar) çökelleri, çalışma alanı içerisinde Hayrettinköy Köyü'nün doğusunda ve Sarıkavak Köyü'nde belirgin olarak gözlenmektedir. Sıkı dokulu traverten çökellerinden oluşan bu birim, kirli beyaz, sarımsı gri ve bej renkli, bitki kök ve kalıpları içeren, paralel laminalanma belirgin ve masif görünümlüdür (ÖSK-IV). Göl içi çökelleri ise, beyaz renkli kiltaşımarnlardan olușmakta ve özellikle Akarca ve Özdemirci Köyü'nün güneyinde tipik olarak gözlenmektedir (Şekil 8d). Akarca Köyü ve çevresinde yoğun olarak gözlenen bu tortullar, gölsel çökelim koşullarının denetiminde depolanmıştır.

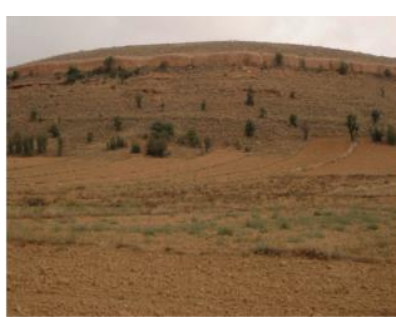

(a)

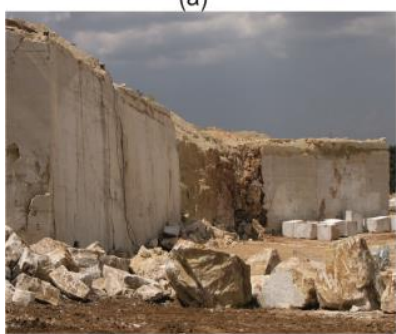

(c) (b)

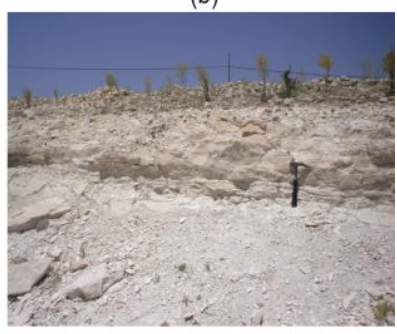

(d)

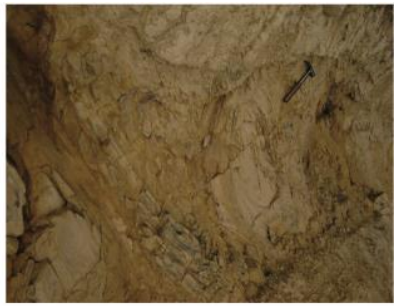

Şekil 8. Çalıșma alanında farklı depolanma ortamlarında çökelmiş tortulların arazideki görünümleri. (a) Kızılören köyü civarında gözlenen kahverengimsi kırmızı renkli karasal çökeller, (b) Çiftlikköyü mevkisinde gözlenen sulatı kayma yapılarının gözlendiği siltli-killi birim, (c) Çiftlikköyü kuzeyinde gözlenen sıcak su çıkışlı traverten oluşumları, (d) Akarca ve Özdemir köyleri arasında gözlenen beyaz renkli marn, killi kireçtaşı birimi

Tablo 1. Çalıșma alanında gözlenen Pliyosen yaşlı Çameli formasyonu ve Pliyo-Kuvaterner yaşlı çökellerin fasiyesleri ve fasiyes ilișkileri

\begin{tabular}{|c|c|c|}
\hline Fasiyes & Açıklamalar & $\begin{array}{l}\text { Depolanma } \\
\text { Sistemi }\end{array}$ \\
\hline $\begin{array}{l}\text { Matriks destekli } \\
\text { çakıltașı fasiyesi (F-1) }\end{array}$ & $\begin{array}{c}\text { Moloz akma } \\
\text { çökelleri }\end{array}$ & \multirow{2}{*}{$\begin{array}{l}\text { Alüvyal } \\
\text { Yelpaze }\end{array}$} \\
\hline $\begin{array}{l}\text { Çapraz tabakalanmalı } \\
\text { kumtaşı fasiyesi(F-2) }\end{array}$ & $\begin{array}{c}\text { Ortaç } \\
\text { yelpaze } \\
\text { çökelleri } \\
\end{array}$ & \\
\hline $\begin{array}{l}\text { Paralel laminasyonlu } \\
\text { çakıllı kumtaşı fasiyesi } \\
\text { (F-3) }\end{array}$ & $\begin{array}{l}\text { Delta üstü } \\
\text { çökelleri }\end{array}$ & \multirow[t]{2}{*}{ Delta } \\
\hline $\begin{array}{l}\text { Deformasyon yapılı } \\
\text { kiltaşı-çamurtaşı } \\
\text { fasiyesi (F-4) }\end{array}$ & $\begin{array}{c}\text { Delta önü } \\
\text { (prodelta) } \\
\text { çökelleri } \\
\end{array}$ & \\
\hline $\begin{array}{l}\text { Biyoturbasyonlu kiltaşı- } \\
\text { marn fasiyesi (F-5) }\end{array}$ & Göl içi & \multirow[b]{4}{*}{ Göl } \\
\hline Laminalı traverten (F-6) & \multirow[b]{2}{*}{$\begin{array}{l}\text { Göl kıyısı } \\
\text { çökelleri }\end{array}$} & \\
\hline $\begin{array}{l}\text { Biyomikritik traverten } \\
\text { (F-7) }\end{array}$ & & \\
\hline Paleosol (F-8) & Göl kıyısı & \\
\hline
\end{tabular}




\section{Tartışma ve Sonuçlar}

\subsection{Tektono-sedimanter evrimi}

\subsubsection{Geç Miyosen-Pliyosen dönemi}

Acıgöl Grabeni, Güneybatı Anadolu'nun günümüzdeki konumunu almasında etkili olan sıkıșma ve genişleme rejimine bağlı, tektonik hareketler sonucu gelişmiş yarı simetrik bir grabendir (Şekil 11). Geç Miyosen süresince Neotektonik dönem, önceki sıkışmaların aksine bir genişleme rejimiyle açıklanmaktadır [27-33]. Batı Anadolu'da Oligosen Dönemindeki karasallaşmayla beraber gelișen sıkışma yerini günümüzdeki KD-GB grabenlerin oluşumuna neden olan KB-GD yönündeki genişleme tektoniğine bırakmıştır (Şekil 9). Bu genişleme süreci günümüze kadar sürmüştür (Şekil 11).

Çalışma alanında bu dönemi yansıtan en belirgin yapısal unsurlar, Acıgöl Grabenini sınırlayan KD-GB gidişli düşey atımlı "Maymundağı Fayı (Çardak Fayı)" ile grabenin güneyindeki sol yönlü bir bileșene sahip "Acıgöl Fayı"dır (Şekil 9). Erken Tortoniyen'de GD yönünde çökerek Acıgöl çöküntüsünü oluşturan bu faylar, basamak faylar oluşturarak günümüze kadar etkinliğini sürdürmüştür. Acıgöl Fayı'nın gelişimiyle yarı graben özelliği kazanan Acıgöl grabeni, daha sonra gelişen Maymundağı Fayı ile grabenin kuzey kenarını da hareketlendirmiștir.

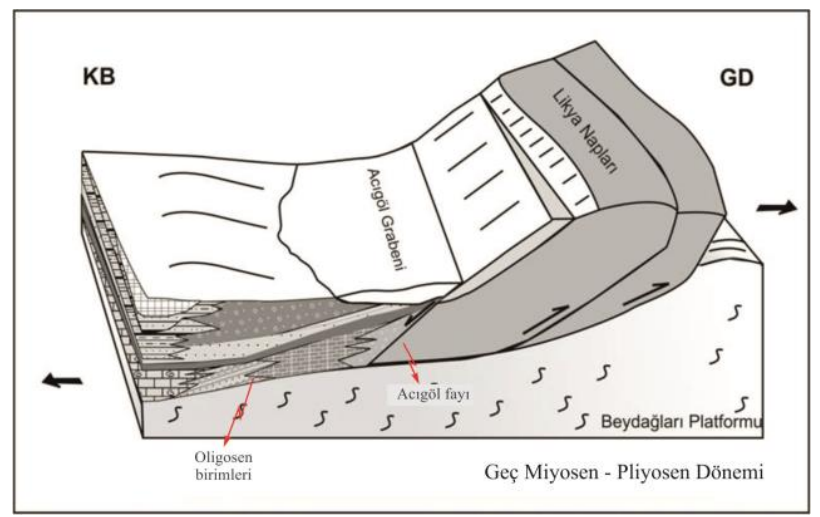

Şekil 9. Çalışma alanında Geç Miyosen-Pliyosen dönemi ve bu dönemdeki çökellerini gösteren blok diyagram. Bu dönemde Acıgöl grabenini oluşturan KB-GD yönünde bir açılma rejimi başlamış ve grabenin güney kenarını faylandırmıştır

\subsubsection{Pliyosen-Kuvaterner Dönemi}

Pliyosen dönemindeki bölgesel genişleme tektoniğine bağlı olarak oluşan traverten çökellerinde orta ölçekte normal faylanmalar gözlenmekte ve bu da travertenlerde bol kırıklı çatlaklı bir görünüm sunmaktadır. Maymundağı Fayı boyunca ve bu faya paralel ve dik olarak gelişen fay sistemlerine bağlı olarak yüzeye doğru hareket eden termal sular, beyaz, bej renkli, bol kırıklı ve çatlaklı, yer yer paleosol seviyelerinin yoğun olarak gözlendiği travertenleri çökeltmişlerdir. Sarıkavak Köyü kuzeyinde görülen bu traverten çökelleri, Sarıkavak
Köyü'nde, Acıgöl çöküntüsüne doğru boşalan akarsuların etrafında biriktirdiği gözenekli, kahverengimsi akarsu tufa çökellerine geçiş göstermektedir. Benzer traverten oluşumları, çalışma alanının kuzey batısında yeralan Hayrettin Köyü’nün doğusunda da görülmektedir [11].

Bu dönem boyunca açılma tektoniğine bağlı olarak gelişen yarı asimetrik Acıgöl Grabeni'nin orta kesimleri $\mathrm{NaSO}_{4}$ 'ca zengin sularla dolmaya başlamıș, sığ-playa tipi göl olarak günümüze kadar varlığını devam ettirmiştir $[1,2,6,10]$ (Şekil 10).

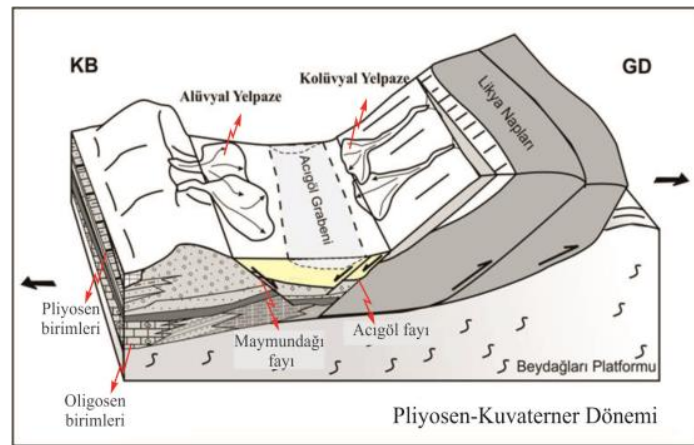

Şekil 10. Çalışma alanının günümüzdeki modeline benzer Pliyosen-Kuvaterner dönemini gösteren blok diyagram

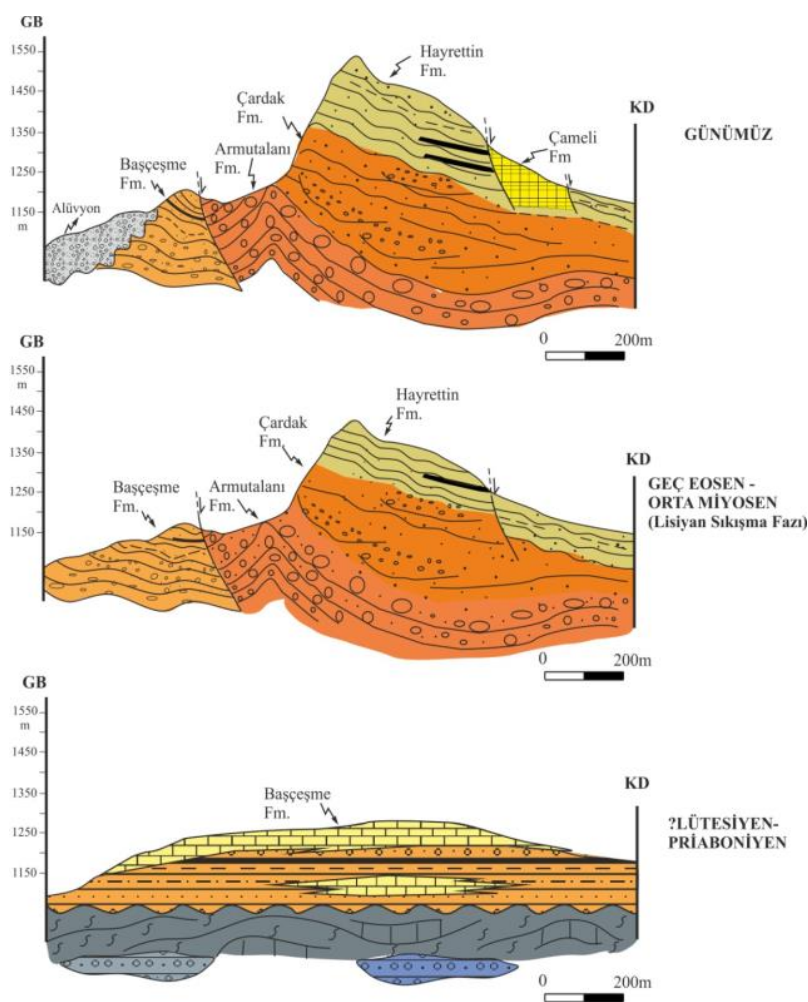

Şekil 11. Çalışma alanı ve çevresindeki Paleojen ve Neojen birimlerin Eosen'den günümüze tektono-sedimanter gelişimi

Bununla beraber, Kuvaterner döneminde Acıgöl graben havzasının güney kenarındaki aktif tektonik hareketlenmeye bağlı olarak kolüvyal yelpazeler gelişmiştir [2,6,10] (Şekil 10). Gölün suyunun giderek çekilmesinden dolayı Yandağ Kireçtaşlarının eteklerinde Acıgöl Fayının önünde, gölsel killi 
kireçtaşı- silttaşı- kiltaşı ardalanması görülmektedir. Grabenin kuzey kenarında gelişen alüvyal yelpazeler, Maymundağı konglomeralarının üzerini yer yer kapatarak belirgin bir morfoloji sunmaktadırlar. (Şekil 10). Acıgöl graben havzasının güney kesimi, kuzey kesimine nazaran daha aktiftir ve daha dik bir topografya sunmaktadır $[6,10]$. Kolüvyal yelpazelerin varlığı da bu savı desteklemektedir $[2,6]$.

Acıgöl Grabeni gibi benzer oluşumlar, özellikle Batı Anadolu'da oldukça belirgin tektonik çöküntüler olarak yer almaktadırlar [1,2,3,5,6]. Acıgöl Grabeni gibi KD-GB uzanımlı komşu grabenler olan Burdur ve Baklan grabenlerin Pliyosen çökelleri, benzer depolanma sistemleriyle temsil edilmektedir [34]. Bu tortullar, Neotektonik dönem ile başlayan genişleme rejimi sonucunda, alüvyal yelpazeden, delta depolanma sistemine ve göl ortamına geçiş gösteren karasal çökelme sistemleri içinde oluşmuşlardır [34].

Bununla beraber, Batı Anadolu'da özellikle Denizli Havzası gibi, Neojen döneminde açılma tektoniğine bağlı olarak gelişen havzalarda, kırık ve çatlaklar boyunca yüzeye çlkan, karbonatça zengin termal suların göl ortamlarını doldurmaya başlamasıyla bölgede kalın geniş yayılımlı traverten istiflerinin oluşmasına neden olmuştur [33,34].

Doğu Akdeniz coğrafyası içinde yer alan bazı Pliyosen havzaları da benzer depolanma sistemleri içinde oluşmuşlardır [35]. Orta İtalya'da Geç Miyosen dönemindeki açılma tektoniği sonucu KB-GD yönünde gelişen Valdelsa Havzası'nın Pliyosen dönemi, alüvyal yelpaze ortamından delta ortamına ve delta çökellerinden şelf ortamına doğru geçiş gösteren karasal ve denizel birimlerle karakterize edilmektedir [35]. Orta İtalya'da travertenleriyle ünlü Siena Havzası'nın Pliyosen dönemi denizel birimlerle karakterize edilirken Kuvaterner dönemi karasal kırıntılılar ve travertenler ile temsil edilmektedir [36,37]. Travertenlerin oluşumunda havzayı sınırlayan Rapolano Fayı'nın rolü oldukça önemlidir ve faya bağlı olarak çıkan kalsiyum karbonatça zengin termal suların bir göl veya havuz içinde çökeltilmeleriyle kalın traverten istifleri gözlenmektedir $[37,38]$.

$\mathrm{Bu}$ çalışma, Acıgöl Grabeni'nin kuzeyindeki PliyoKuvaterner yaşlı birimlerin ayrıntılı sedimantolojik incelemesinden oluşmaktadır. Elde edilen veriler ıșığında toplam 8 litofasiyes birimi tanımlanmıştır. $\mathrm{Bu}$ lithofasiyes birimleri, alüvyal yelpaze, delta ve göl olmak üzere 3 farklı depolanma sistemi içinde karakterize edilmektedirler.

Bölgede aktif tektonik hareketlenmenin varlığgl, grabeni sınırlayan ana fayın (Maymundağı Fayı) sintetik ve antitetik faylarına bağlı olarak karbonatça zengin sular, kırık ve çatlaklardan yüzeye çıkarak Çameli formasyonunun üst kesimlerinde görülen traverten ve tufa gibi Kuvaterner yaşlı karasal karbonatları oluşturmuşlardır. Bu çalışmada yer alan travertenler üzerine yaplacak ayrıntılı sedimantolojik ve palinolojik çalışmalar, bölgenin geniş kapsamlı paleoiklimsel ve paleovejetasyonel gelişimine ışık tutacaktır.

\section{Teşekkür}

$\mathrm{Bu}$ çalışma, Ezher Toker'in Doktora çalışma konusuyla başlayan ve ilerleyen zamanlarda Kuvaterner yaşlı karasal karbonat çökellerinin ayrıntılı çalışmalarıyla devam eden araştırmaların bir kısmını içermektedir. Pamukkale Üniversitesi Bilimsel Araştırma Projesi (BAP, Proje No: 2014HZL010) ile desteklenen bu çalışmanın makale aşamasında değerlendirmelerini yapan, görüş ve önerilerini yapıcı bir şekilde sunan tüm hakemlere katkılarından dolayı sonsuz teşekkür ederiz.

\section{Kaynakça}

[1] Mutlu, H., Kadir, S., Akbulut, A. 1999. Minerology and Water chemistry of the Lake Acıgöl, Denizli, Turkey. Carbonates and Evaporites 14 (2) 191199.

[2] Koçyiğit, A. 2005. The Denizli graben-horst system and the eastern limit of western Anatolian continental extension: basin fill, structure, deformational mode, throw amount and episodic evolutionary history, SW Turkey. Geodinamica Acta 18, 167- 208.

[3] Price, S, P., Scott, B. 1994. Fault-block rotations at the edge of a zone of continental extension, southwest Turkey. Journal of Structural Geology, 16, 381-392.

[4] Göktaş, F., Çakmakoğlu, A., Tan, E., Sütçü, Y.F., Sarıkaya, H. 1989. Çivril-Çardak Arasının Jeolojisi. MTA Rap. No: 8701, 109s., Ankara.

[5] Sözbilir, H. 2005. Oligocene-Miocene extension in the Lycian orogen: evidence from the Lycian molasse basin, SW Turkey. Geodinamica Acta 18, 255-282.

[6] Toker, E. 2009. Acıgöl-Çardak (Denizli) Grabeninin Kuzeyindeki Tersiyer Çökellerinin Tektono-Sedimanter Gelişiminin İncelenmesi, Doktora Tezi, 242, Isparta.

[7] Şenel, M. 1997. Denizli-J9, 1/100.000 Ölçekli Jeoloji Haritası ve Açıklamalı Kitapçı̆̆ı. MTA Yayınları, 18s., Ankara.

[8] Sözbilir H. 2002. Revised stratigraphy and facies analysis of the Palaeocene-Eocene supraallochthonous sediments and their tectonic signifi cance (Denizli, SW Turkey). Turkish Journal of Earth Sciences 11, 1-27.

[9] Alçiçek, M.C., Kazanci, N., Özkul, M., Şen Ş. 2004. Çameli (Denizli) Neojen havzasının tortul 
dolgusu ve jeolojik evrimi. MTA Dergisi, 128, 109-123.

[10] Helvacl, C., Alçiçek, M. C., Gündoğan, İ., Gemici, Ü. 2013. Tectonosedimentary development and palaeoenvrionmental changes in the Acıgöl shallow-perennial playa-lake basin, SWAnatolia, Turkey. Turkish Journal of Earth Science, 22, 285-291.

[11] Toker, E. 2015. Preliminary Results of the Quaternary Sarkavak Tufa Deposits as Palaeoenvironmental and Palaeoclimatic Indicators (Denizli-SW Turkey). 31st IAS Meeting of Sedimentologists, 22-25 June, Krakow, Poland.

[12] Tagliasacchi (Toker) E., Kayseri-Özer, M.S. 2018. Palaeoclimate Changes in the Afyon Province, SW-Turkey, During the Middle-Late Pleistocene: Signals From Calcareous Tufa Pollen and Stable Isotope Records. Alpine and Mediterranean Quaternary, Vol. 31 (Quaternary: Past, Present, Future - AIQUA Conference, Florence, 13-14 June 2018), 161 - 164.

[13] Akkiraz, M. S., Akgün, F. 2005. Palynology and age of the Early Oligocene units in Çardak-Tokça basin, southwest Anatolia: paleoecological implications. Geobios-Lyon 38: 283-299.

[14] Koçyiğit, A. 1984. Güneybatı Türkiye ve Yakın Dolayında Levha İçi Yeni Tektonik Gelişimi. T.J.K. Bült., 27,1-15.

[15] Miall, A.D. 1978. Tectonic Setting and Syndepositional Deformation of Molasse and Other Nonmarine-Paralic Sedimentary Basins, Canadian J.Earth Science, 15, 1613-1632.

[16] Yağmurlu, F., Bozcu, M., Şentürk, M. 2005. Burdur-Fethiye arasındaki bölgede Burdur fayının sismotektonik özelliklerinin araştırılması. TÜBİTAK Raporu, 80s., Isparta.

[17] Sözbilir, H. 1997. Sratigraphy and Sedimentology of The Tertiary Sequences in The Northeastern Denizli Province (Southwest Turkey), Doktora Tezi, 195s., İzmir.

[18] Philipson, A. 1915. Reisen und Forshuhgen in Westlichen Kleinasien. Pett. H.,167.

[19] Şenel, M., Akdeniz, N., Öztürk, E.M., Özdemir, T., Kadınkız, G., Metin, Y., Öcal, H., Serdaroğlu, M., Örçen, S. 1994. Fethiye (Muğla)-Kalkan (Antalya) ve Kuzeyinin Jeolojisi, MTA Rap. 9761, 121 s., Ankara.

[20] Akkiraz, M.S., Akgün, F., Örçen, S., Bruch, A. A., Mosbrugger, V. 2006. Stratigraphic and Palaeoenvironmental Significance of BartonianPriabonian (Middle-Late Eocene) Microfossils from the Başçeşme Formation, Denizli Province, Western Anatolia. Turkish Journal of Earth Science, 15, 155-180.
[21] Şahbaz, A., Görmüș, S. 1992. Çardak (Denizli) Kuzeyindeki Eosen-Oligosen Yaşlı Konglomeralarm Stratigrafik ve Sedimantolojik İncelemesi. Türkiye 9. Petrol Kongresi ve Sergisi, 62-74s., Ankara.

[22] Erakman, B., Meşhur, M., Gül, M.A., Alkan, H., Öztaş, Y., Akpınar, M. 1982. Fethiye-KöyceğizTefenni-Elmalı-Kalkan Arasında Kalan Alanın Jeolojisi. Türkiye Altıncı Petr. Kong. Tebl. Nisan, 23-31, Ankara.

[23] Toker, E. 2017. Quaternary fluvials tufas of Sarıkavak area, southwestern Turkey: Facies and depositional systems. Quaternary International, Nonmarine Carbonates, Special Issue, 437, 37-50.

[24] Miall, A.D. 1984. Principles of Sedimentary Basin Analysis, University of Toronto, Department of Geology, Toronto, M5s 1a1, 490p., Canada.

[25] Folk, R.L., 1962. Spectral Subdivision of Limestone Types. (Ham, W.E., -eds.). Classification of Carbonate Rocks. Am. Ass. Petrol. Geologist Mem. 1, 62-84.

[26] Dunham, R.J., 1962. Classification of Carbonate Rocks According to Depositional Texture. (Ham, W.E., -eds.). Classification of Carbonate Rocks. Am. Ass. Petrol. Geol. Mem.1, 108-121, Ulsa.

[27] Seyitoğlu, G., Scott, B.C., Rundle, C.C. 1992. Timing of Cenozoic extensional tectonics in west Turkey. Journal of the Geological Society, London, 149, 533-538.

[28] Şengör, A.M.C. 1982. Ege'nin tektonik evrimini yöneten etkenler. Batı Anadolu'nun Genç Tektoniği ve Volkanizması Paneli, s.59-72.

[29] Şengör, A.M.C., Yllmaz, Y. 1983. Türkiye'de Tetis'in Evrimi: Levha Tektoniği Açısından Bir Yaklaşım. Türkiye Jeoloji Kurumu, Yerbilimleri Özel Dizisi,1.

[30] Gürer, Ö.F., Sarıca-Filoreau, N., Özburan, M., Sangu, E., Doğan, B. 2009. Progressive development of the Büyük Menderes Graben based on new data, western Turkey. Geol Mag 146: 652-673.

[31] Gürer , Ö.F., Yılmaz, Y. 2002. Geology of Ören and surrounding areas, SW Anatolia. Turkish Journal of Earth Science. vol 11, 1-13.

[32] Price, S. P., Scott, B., 1991. Pliocene Burdur Basin, SW-Turkey: tectonics, seismicity and sedimentation. Journal of the Geological Society, London, Vol. 148, 1991, pp. 345-354,

[33] Toker, E., Kayseri-Özer, M.S., Özkul, M., Kele, S. 2015. Depositional system and palaeoclimatic interpretations of Middle to Late Pleistocene travertines: Kocabaş, Denizli, south-west Turkey. Sedimentology, 62, 5, 1360-1383. 
[34] Özkul, M., Kele, S., Gökgöz, A., Shen, C., Jones, B., Baykara, M.O., Fòrizs, I., Németh, T., Chang, Y. and Alçiçek, M.C., 2013. Comparison of the Quaternary travertine sites in the Denizli extensional basin on their depositional and geochemical data. Sed. Geol., 294, 179- 204.

[35] Benvenuti, M., Degli Innocenti, D., 2001. The Pliocene Deposits in the Central Eastern Valdelsa Basin (Florence, Italy) Revised Through Facies Analysis and unconformity-Bounded Stratigraphic units. Rìvìsta Italiana dì Paleontologia e Stratigrafia. Vol. 107, 2, 265-286.

[36] Guo, L., Riding, R. 1998. Hot-spring travertine facies and sequences, Late Pleistocene Rapolano Terme, Italy. Sedimentology 45, 163-180.

[37] Brogi, A., Capezzuoli, E. 2009. Travertine deposition and faulting: the fault-related travertine fissure-ridges at Terme S. Giovanni, Terme, Italy. International Journal of Earth Sciences 98, 931-947.

[38] Brogi, A., Capezzuoli, E., Aqué, R., Branca, M. Voltaggio, M. 2010. Studying travertines for neotectonics investigations: Middle-Late Pleistocene syn-tectonic travertine deposition at Serre di Rapolano (Northern Apennines, Italy). Int. J. Earth Sci., 99, 1383-1398. 